Pure \& Appl. Chem., Vol. 55, No. 12, pp. 1989-2006, 1983. Printed in Great Britain
0033-4545/83\$3.00+0.00 Pergamon Press Ltd. (c)1983 IUPAC

\title{
ROLE OF SAMPLE DECOMPOSITION AND PRECONCENTRATION IN ELEMENTAL TRACE ANALYSIS
}

\author{
Günther Tölg
}

Institut für Spektrochemie und angewandte Spektroskopie in Dortmund and Laboratorium für Reinststoffanalytik am Max-Planck-Institut für Metallforschung in Stuttgart, D-4600 Dortmund 1, Bunsen-KirchhoffStraße 11, Federal Republic of Germany

\begin{abstract}
Progress in elemental trace analysis means that lower concentrations can be determined in a more reliable and efficient way. The demands posed to trace element analysis follow generally the tendency that lower and lower concentrations should be determined in matrices which become more and more complex. The most economical scientific strategy depends strongly on the element to be determined, on the kind of sample and especially, on the power of detection. Therefore, we must develop the strategy of determination in view of two widely differing thoughts:

1. It is necessary to apply direct instrumental methods for routine analysis in order to save time and man-power. This can be done only, if the required power of detection is asserted in view of a sufficient reliability of the results.

2. Multi-stage combined procedures have to be preferred in all cases, where direct instrumental methods still yield insufficient or incorrect results, in spite of the fact that they are usually more time and/or labour consuming.

This paper intends to concentrate in particular on these procedures, in which decomposition and preconcentration methods have to precede the actual end-determination. The main goal is the minimization of systematic errors which become more crucial at the low concentrations involved. Especially those combined methods of a high degree of universality and reliability will be considered.
\end{abstract}

Examples will be given for the determination of $\mathrm{Hg}$, Se, $\mathrm{Tl}$ and $\mathrm{B}$ at $\mathrm{ng} / \mathrm{g}$ and $\mathrm{pg} / \mathrm{g}$ levels.

\section{INTRODUCTION}

Progress in the field of trace analysis of the elements concerns the capability of reliable and economical determination of extremely low element contents in samples of very complex composition as they occur in all fields of natural science, medicine and technological science. However, with the ever increasing demand on the power of detection, the question for the most economic approach can no longer be treated separately. It depends foremostly on the degree of attainable reliability of results which is only partly determined by the method employed,but even more by the concentration range, the kind of element to be determined and the complexity of the matrix. In addition to the usual random statistical errors of the analytical method, increasing systematic errors occur overwhelmingly with lower amounts of elements to be determined. These systematic errors may falsify the analytical results by several orders of magnitude in extreme cases in spite of good reproducibility of the results (Ref. 1). In fact, this is confirmed more and more frequently, by interlaboratory comparative analyses (Ref. 1, 2, 3). The necessity to decide about the entire conception of economy in view of analytical methods is raised from two perspectives:

1. The demands posed to the power of detection are less rigid in the case of analyses at the $\mu \mathrm{g} / \mathrm{g}$ level. The most economic approach is the application of instrumental methods for multielement determina- 
tion. If possible a direct sample excitation should be chosen allowing a relatively simple sample treatment. Computer aided evaluation (e.g., SSMS, INAA, XFRA, PIXE, ICP-OES) is helpful. In this way good results are obtained provided that a sufficient number of certified reference materials is available.

2. The other extreme occurs in case lowest element contents or smal1est absolute amounts of elements have to be determined; available determination methods have to be considered in view of their power of detection (ng/g- respectively pg/g-analysis). Then the optimal economic way of the analytical approach will have to change. Since false or unreliable results are considered to be more expensive (e.g., safety and health) than analytical costs the idea of an economically controlled approach becomes obsolete. The additional costs of a more detailed analysis using multi-stage procedures are easily amortized by avoiding incorrect results.

In extreme trace analysis of the elements, highest power of detection and at the same time, best reliablility of results requires, that the element to be determined is completely separated from any concomitant sample components, and then determined in its final, isolated, thus separated state. In this manner, interferences by interelement effects during excitation of the sample are most efficiently avoided; consequently, a method can be calibrated with high accuracy. From the economical point of view, one obtains a particularly wide applicability of an analytical procedure due to the highest degree of matrix independence (Ref. $1,2,4)$.

In practice, most of the trace-analytical problems imposed lie on a scale between these two extremes; the economical aspects of an analytical strategy have to be considered from both ends of this scale and applied accordingly. A compromise has to be reached depending on the required reliability of the data. It is by far the most difficult and as yet hardly solved task, to find the most appropriate strategy in each event of trace analysis.

These interrelationships between power of detection, reliability and economical aspects of an analytical method elucidate that sample preparation in trace-analytical methods should only then be propagated if the solution of the analytical problem so requires. Any kind of additional sample treatment prior to an instrumental determination method demands extra time and man-power and has therefore to be weighed against the advantages derived. Further, this cost/profit relationship differs for different countries, depending on the local man-power costs. In a number of countries, therefore preference is given to multi-stage combined procedures (sample decomposition, preconcentration and determination) over expensive instrumental techniques of direct analysis.

The very limited space does not permit my reference to details concerning the above particular case which would presuppose a very extensive systematic survey. The immense number of current high-performance methods of analysis in which a sample treatment is included, requires an individual examination of every new problem in trace analysis. Any generalization of experiences may cause damage instead of bringing profit. Summarizing, one can state, that in the field of extreme trace analysis there are no simple solutions, unfortunately.

For these reasons, the first part of this paper is dedicated to the few, most important principles necessary to avoid systematic errors in multi-stage procedures which bear generalization.

In the course of the second part, some detailed ways of problem solving are exemplified by the determination of mercury, selenium, thallium and boron. The aspect of multi-stage procedures at the $\mathrm{ng} / \mathrm{g}-$ and $\mathrm{pg} / \mathrm{g}$ levels is emphasized in view of universality and reliability of such methods, provided that instrumental direct analysis does not solve the analytical problem.

\section{RECOGNITION, CAUSES AND AVOIDANCE OF SYSTEMATIC ERRORS}

Our main considerations are focussed once more on the recognition (Table 1), the causes (Table 2) and the avoidance of systematic errors. In the course of multi-stage procedures these errors occur in particular during decomposition and separation procedures. The reliable determination of the isolated element traces generally imposes minor problems. 
TABLE 1. Recognition of Systematic Errors

1. Use of certified reference materials

2. Interlaboratory comparative analyses

3. Application of independent systems of analysis

4. Application of absolute methods of determination

5. Application of easily calibrated, multi-stage procedures (calibration with standard solutions according to the incremental method, calibration graphs)

6. Addition of increasing quantities of the same sample

7. Yield determination using radio-tracers with the same type of binding (e.g., by activation of the sample)

8. Statistical evaluation of normal distribution of errors (outlier test)

9. Check of any dependence of the results on sample weight, time, amounts of reagents, temperature, etc.

Concerning the avoidance of systematic errors, the general rule, unchanged and well-established over a period of time, still prevails (Ref. 5):

Least systematic errors during the course of an analytical procedure require that

a) only if absolutely necessary, multi-stage operations are performed;

b) using closest possible interconnected operational modes;

c) in reaction chambers of smallest possible surface areas;

d) at lowest possible temperatures;

e) all contact materials should be as indifferent as possible and should not contain the elements to be determined;

f) exclusion of contamination risks from dust particles in laboratory air;

g) the analytical yield of each single step in a multi-stage procedure has to be thoroughly checked independently and where possible using radiotracers (Ref. 6).

TABLE 2. Causes of Systematic Errors

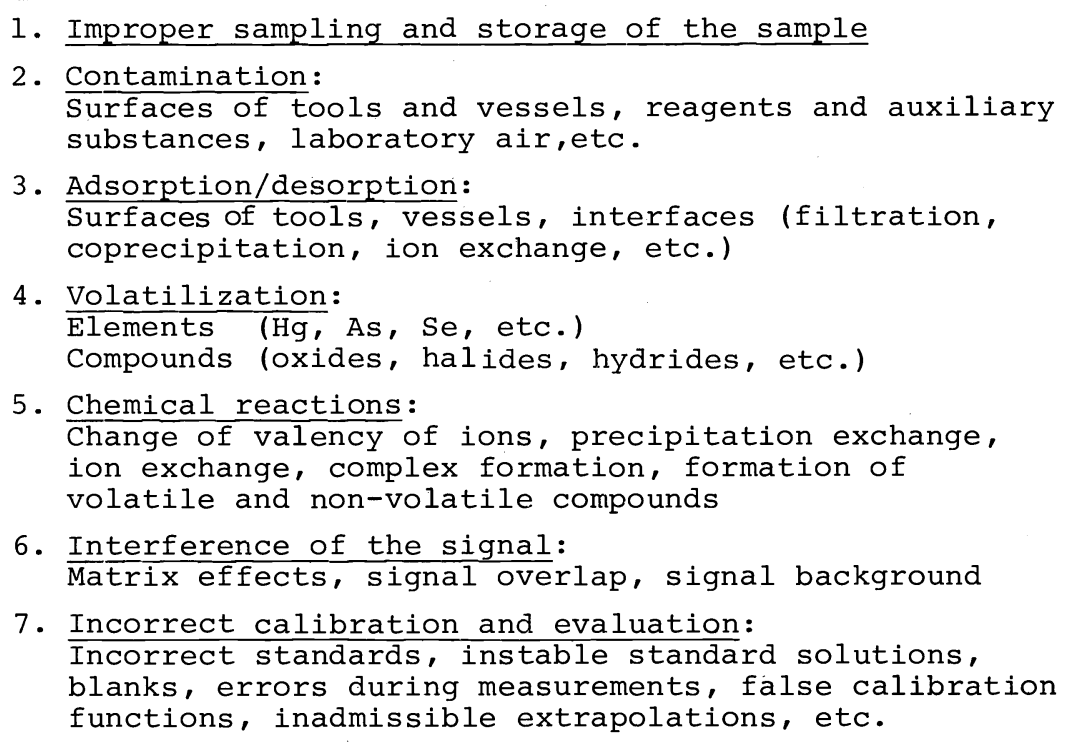


The introduction of these fundamental stipulations into the analytical practice can be referenced here only by the particularly serious problems of contamination and blank values, respectively. Concerning both these problems it must be emphasized that

1. often, not the sensitivity level of a detector system but the blank concentration of the elements limits the power of detection and the reliability of a trace-analytical procedure,

2. in particular, high blank levels of elements of the common constituents in the environment occur generally (such as Si, Al, Ca, Mg, $\mathrm{Fe}, \mathrm{Mn}, \mathrm{Na}, \mathrm{K}, \mathrm{Ti}, \mathrm{P})$.

It is therefore necessary that these values are kept very low and constant. In order to cope with such difficult tasks one has to start with the choice of the most suitable materials for instruments (e.g., preferentially quartz, PTFE, PP, glassy carbon) and with the cleaning of the material surfaces. To summarize systematic investigations (Ref. 7, 8), it was found that one may get serious problems with respect to blanks already by such simple operations as cleaning of the vessels (e.g., rinsing with acids and water). The given example in the case of magnesium (see Fig. 1) shows that the only cleaning technique

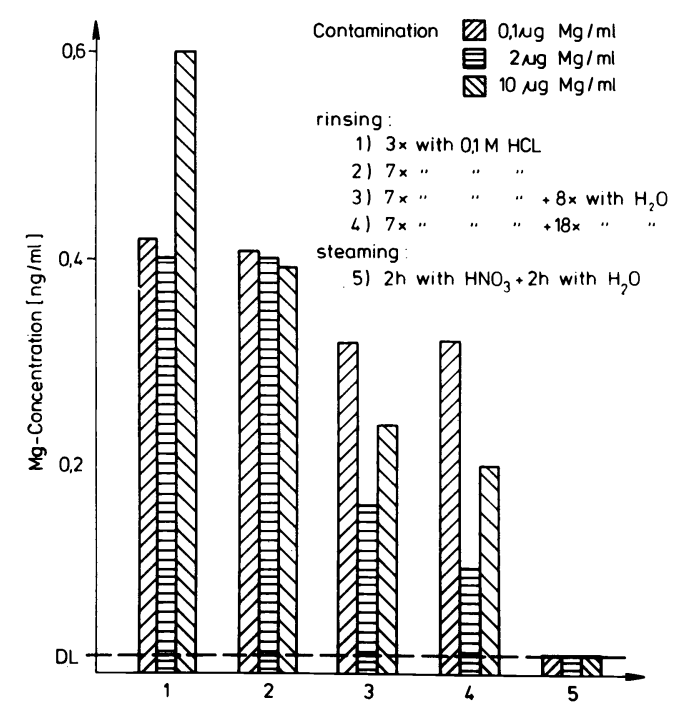

Fig. 1 Magnesium contents of water in $50 \mathrm{~mL}$ flasks after different cleaning procedures

leading to low and constant blank values is the treatment of vessels with vaporized acid and water in a special evaporization device (see Fig. 2) over a longer period. The behaviour of other elements is similar. Also, the purification of the reagents demands special techniques, e.g., the distillation of acids below their boiling points in special apparatus made of quartz, PTFE or PP (see Fig. 3). Frequently, it is necessary to work in "clean rooms", to reduce contamination risks by element traces widely distributed in the laboratory air.

Further details on how to avoid systematic errors during sampling, storage of samples, pulverization and homogenization of the sample material, during dosage of solutions or sample decomposition and during all steps of preconcentration which cannot referred to in detail here, are found in the literature (Ref. 5, 9-14). It must be emphasized that in fact, all these errors do contribute to the total incorrect result of the analytical procedure. Developing new multi-stage procedures requires thorough controls and special measures of each single step of such procedures. This is given in the following sections, for some practical examples. 


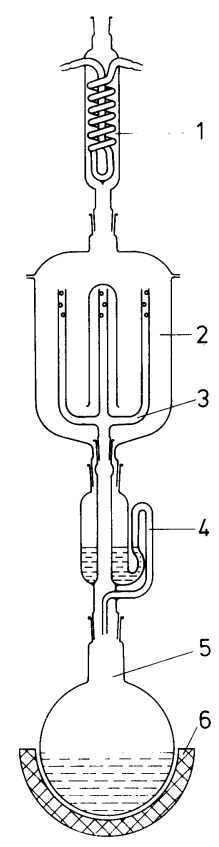

1 reflux condenser

2 steaming chamber

3 vapour tube

4 overflow

5 stock vessel

6 heating

Fig. 2 Steaming apparatus (quartz) for vessel cleaning in nitric acid vapour or water vapour (Ref. 5)

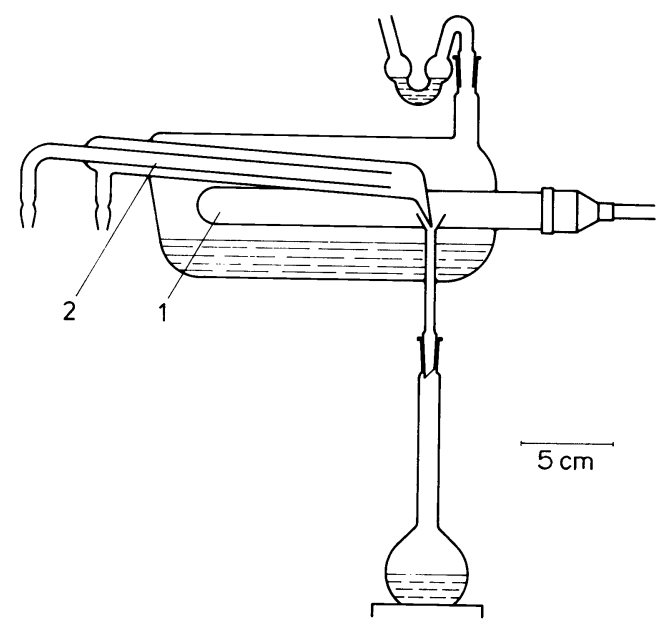

1 heating

2 condenser

Fig. 3 Sub-boiling point distillation apparatus (Ref. 5)

III. DECOMPOSITION METHODS

The problem to avoid systematic errors during decomposition of the sample is particularly serious since there does not exist any universally applicable decomposition method that meets all requirements of trace analysis. So one has to refer to the appropriate decomposition principle valid for an analytical problem. Only some of the most essential decomposition techniques that are suitable for extreme trace analysis are summarized here (Ref. 2, 15, 16). They will be referred to in more detail only if required for the elucidation of the subsequent analytical examples described. Wet digestion procedures with oxydizing agents, e.g., $\mathrm{HNO}_{3}, \mathrm{HClO}_{3}, \mathrm{HClO}_{4}, \mathrm{H}_{2} \mathrm{O}_{2}$ are suited best for both, large sample throughputs and sample weights, but cause inherently problems of contamination und losses of elements by volatilization. Biotic matrices with a high fat content can only be completely decomposed with a mixture of $\mathrm{HNO}_{3}$, $\mathrm{HClO}_{4}$ and $\mathrm{H}_{2} \mathrm{SO}_{4}$ (Ref. 17) or $\mathrm{HNO}_{3}$ and $\mathrm{H}_{2} \mathrm{SO}_{4}$ in a special apparatus (Ref. 18 ). 
Some difficulties in purifying $\mathrm{H}_{2} \mathrm{SO}_{4}$ limit in particular the application of this method in the extreme trace analysis. A mechanized apparatus for the wet decomposition allows for high sample rates (Ref. 16).

Numerous systematic errors in the decomposition of inorganic and organic materials are reduced by decomposition in PTFE pressure bombs using oxydizing acids like $\mathrm{HNO}_{3}$. Pressure decomposition requires small acid volumes only and prevents losses of volatile elements (e.g., Hg, As, Se).

Most of the serious errors with organic samples are introduced by the low sample weight which is strictly limited to $0.5 \mathrm{~g}$ for reasons of safety. A frequently ignored fact is that no quantitative mineralization is achieved at normal conditions. This is, however, absolutely necessary for voltammetric determination methods. For e.g. $\mathrm{HNO}_{3}$, sufficiently high oxidation potentials are obtained only at decomposition temperatures $2220^{\circ} \mathrm{C}$ in vessels made of glassy carbon (Ref. 19) or quartz (Ref. 20).

For a determination of low concentrations of more common elements, combustion in pure oxygen should be given preference over wet decomposition methods on account of a small risk of contamination. There are two alternatives:

a) The combustion in an oxygen plasma excited by a high frequency (Ref. 21, 22) or UHF (Ref. 23) field: especially the second mode offers great advantages in extreme trace analysis. A versatile applicable decomposition apparatus is commercially available.

b) The combustion in molecular oxygen can be carried out in an autoclave under pressure* (see Fig. 4) (Ref. 14) or according to the principle of a quasi-static combustion (Ref. 25, 26) (Trace-0$\left.\mathrm{Mat}^{\circledR}\right) * *$
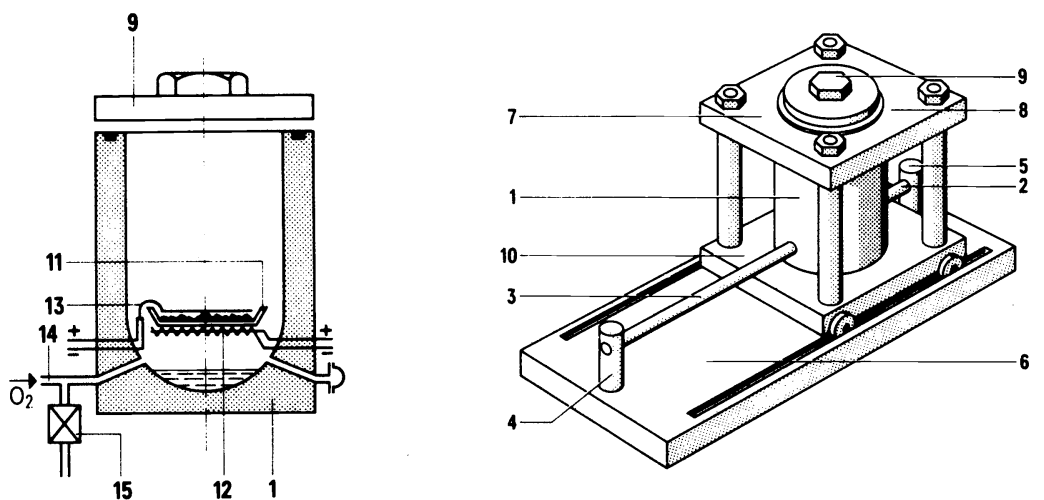

Fig. 4 Principle of the Bioklav ${ }^{\circledR}$

1 pressure vessel (stainless steel); 2 \& 3 support bar; 4 \& 5 mounting blocks; 6 bottom plate; 7 \& 8 upper pressure bearing plate; 9 locker screw nut; 10 bottom pressure bearing plate; 11 sample tray; 12 Ptheating wire; 13 Pt-ignition wire; 14 oxygen inlet; 15 pressure check valve for oxygen

Using a quartz apparatus (see Fig. 5) with a cooling finger (liquid nitrogen) sample weights up to $1 \mathrm{~g}$ can be burnt completely in a combustion chamber of only $75 \mathrm{~cm}^{3}$ without loss of volatile elements, e.g., Hg, Se, As, I.

The latter method allows complete separation of elements like $\mathrm{Hg}, \mathrm{Cd}, \mathrm{Pb}, \mathrm{Tl}$, $\mathrm{Bi}$, Se by volatilization from non-volatile matrix components like $\mathrm{Cu}, \mathrm{Fe}, \mathrm{Ni}$, $\mathrm{Co}, \mathrm{Mn}, \mathrm{Al}$, and silicates during the decomposition step (Ref. 27). Inorganic samples will be mixed in their pulverized form with e.g., high purity cellulose powder and pressed into pellets which will be ignited by the IR-lamp of the apparatus via a cellulose strip.

Note *: Bioklav ${ }^{\circledR}$, Siemens AG, E 689, Postfach 211262, D-7500 Karlsruhe 21 Note **: Trace-O-Mat ${ }^{\circledR}$, Anton Paar KG, Postbox 58, A-8054 Graz 
While the first method (a) was designed for routine work in the $\mu \mathrm{g} / \mathrm{g}-\mathrm{range}$ only admitting sample weights in the g-range, the second one (b) is intended primarily for extreme trace analysis. Both methods perfectly supplement each other and offer enormous improvements for destruction of biological materials.

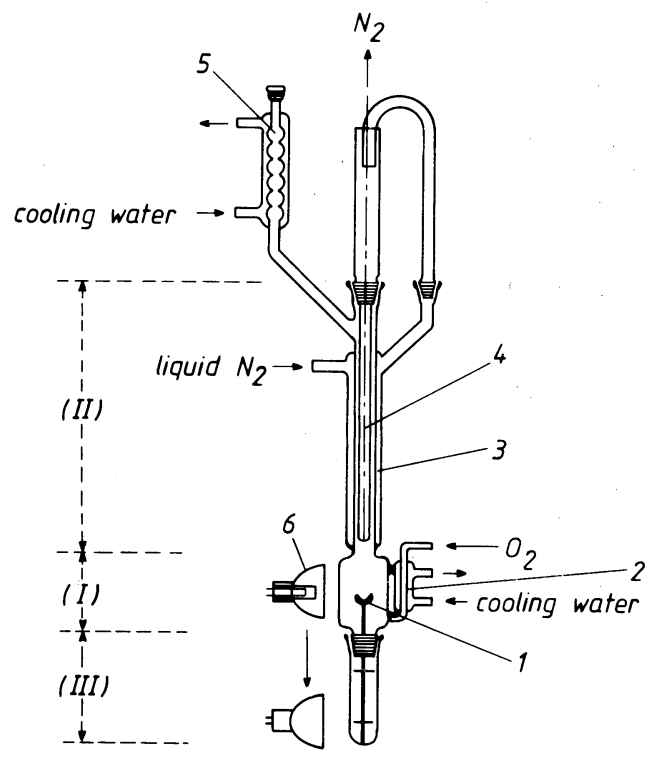

(I) combustion chamber

(II) liquid nitrogen cooling system

(III) reagent tube of quartz

1 sample holder

2 capillary with cooler for oxygen supply

3 cooling chamber

4 cooling tube

5 reflux condenser

6 IR-lamp

Fig. 5 Combustion unit (quartz) of the Trace-O-Mat ${ }^{\circledR}$

Organic components (e.g., humic substances) in aqueous samples are (advantageously) decomposed by photolytic mineralization using an UV-lamp in the presence of $\mathrm{H}_{2} \mathrm{O}_{2}$ or other oxydizing agents (Ref. 28-30). This procedure can effectively be applied even prior to voltammetric determination methods.

\section{SEPARATION AND PRECONCENTRATION METHODS}

The field of separation and preconcentration methods (Ref. 31-38) is too complex to show direct pathways to solve a problem. Merely some general points of view can be pointed at briefly. Decisive advantage is yielded for those elements, e.g., Hg, As, Sb, Se, Te that can be separated by volatilization from the mineral phase either directly or via easily formed volatile compounds, e.g., hydrides, halides or oxides. Thus, the separation step can be directly tied firmly to the decomposition step resulting in an efficient state of the art multi-stage procedure for the determination of, e.g., $\mathrm{Hg}, \mathrm{Se}, \mathrm{Tl}$, and $\mathrm{B}$ as will be shown in sect. VI.

Similarly, we can meet today's requirements by modification of conventional separation principles that can jointlessly be included in a multi-stage system. Extreme examples of the high-purity materials analysis are precipitation exchange on thin layers or electrolytical separation methods which can, in many modifications, be transferred to other trace-analytical problems (Ref. 4). Excitation methods, too, can essentially be optimized, if their techniques are approximated to the "single-vessel principle", i.e. if the ectraction is carried out directly in the decomposition flask, e.g., in a PTFE tube which is used to separate the phases. This way, we succeeded, for instance, in determining the distribution of $\mathrm{Be}$ at $\mathrm{pg} / \mathrm{g}$-levels in the individual protein fractions of blood serum (Ref. 30, 39). Using chelate GC (Ref. 41) and chelate HPLC (Ref. 42) numerous - even simultaneous - separations of elements in the ng/g-range are possible in which - moreover - the separated species can be determined at lower levels. The close coupling of the separation and determination step enables a considerable progress with relatively simple means. 
V. MOTIVATIONS AND EXAMPLES FOR THE DEVELOPMENT OF PARTICULAR, UNIVERSAL AND MOST SENSITIVE MULTI-STAGE PROCEDURES

The main aspects to improve the detection abilities in elemental trace analysis are of long term validity and therefore, unchanged since the last ISM in Graz (Ref. 43).

In the investigation of biotic and environmental systems, today's methods to determine the total concentrations of the elements of interest (mostly in the range $\geq 1 \mathrm{ng} / \mathrm{g}$ ) must be completed by methods which are more sensitive by a factor of at least 20. This is a prerequisite in order to investigate also the distribution of the elements and their species,e.g., in tissues, cell compartments and individual protein fractions of the blood serum (micro-trace analysis). Further, trace elements with a high biological activity (e.g., Hg, Cd, $\mathrm{Pb}, \mathrm{Tl}, \mathrm{Se}, \mathrm{As}, \mathrm{Be})$ must be simultaneously determined in a broad spectrum of matrices (e.g., rocks, water, air, soils, plants, animals, food-stuffs, and above all, in the human body) to study their complex ambivalent, antagonistic or synergistic properties, and to be able to compare the analytical data under interdisciplinary aspects. Therefore, the analytical procedures should be universally applicable and of high accuracy, even in the pg/g-range.

The conditions are quite different regarding numerous materials which have been created by man within the scope of modern technology. Here, detection limits to be aimed at lie also in the $\mathrm{ng} / \mathrm{g}$ und $\mathrm{pg} / \mathrm{g}-\mathrm{range}$, but the $\mathrm{risk}$ of systematic errors with respect to the more complex matrices (e.g., high-purity metals, semi-conductors, optical wave guides, ceramics for implantates) increases, as compared to organic samples. Therefore, here multi-stage procedures are still of high importance.

As a result, reliable, multi-stage procedures have to be developed which are suitable - also for routine analysis - for the determination of elements within a broad spectrum of matrices at ng/g levels and below. Many pathways promise to lead to this goal and are therefore pursued in element determinations of high sensitivity by using nearly all familiar principles of analysis. Consequently, the main difficulty lies in a critical comparison of the methods to find out the optimal combinations. There is no chance for one laboratory to fulfil this task for all elements of interest. During many years we have been in the favourable situation of investigating and optimizing in detail some of the most efficient determination principles for some important elements, e.g., $\mathrm{Hg}, \mathrm{Se}, \mathrm{Tl}$, and $\mathrm{B}$, in many metallic, geochemical and organic materials. The strategy we followed is very similar in each case. The first step was to find out and to prove the most sensitive determination methods for an element in its isolated form. This gives us the order of magnitude of the limit of determination which might be reached at the best. Then, we had to look for the optimal methods of sample decomposition and for the separation of the element to be determined from all concomitant elements in a sample and to combine these steps with the suitable, most sensitive determination methods. All known rules to avoid systematic errors have to be taken into consideration. The long ways of development of the procedures cannot be discussed here for each case. We often made mistakes, but positive and negative experiences increasingly gathered headway. Here, only the results can be given.

VI. UNIVERSAL AND ACCURATE DETERMINATION PROCEDURES FOR Hg, Se, Tl, AND B IN THE ng/g AND pg/g LEVEL

\section{Determination of mercury}

From Table 3 we selected MIP-OES as the most sensitive and highly selective determination method for $\mathrm{Hg}$. The high volatility of $\mathrm{Hg}$ and all its compounds allows to seperate it from inorganic and organic matrix compounds during the decomposition step by heating or burning the sample by microwave-excited oxygen (see Fig. 6). The resulting $\mathrm{Hg}$-vapour is collected on a gold absorber system. By heating this after the complete Hg-collection, the Hg-vapour passes a quartz capillary where $\mathrm{Hg}$ amounts $\geq 1 \mathrm{pg}$ can be monitored at $253.7 \mathrm{~nm}$ by Ar-MIP-OES. This multi-stage procedure shows a nearly ideal combination to minimize all blanks and other systematic errors. Only systematic errors yet introduced during sampling and sample preparation can influence the accuracy of the method.

For the determination of $\mathrm{Hg}$ amounts $\geq 0.1 \mathrm{ng}$, the procedure of sample decomposition in the Trace-o-Mat combined with cold vapour technique involving a subsequent preconcentration of the $\mathrm{Hg}$ at the Au-absorber system and determination of the collected $\mathrm{Hg}$ by AAS in an open PTFE-cell system proves to be also 
very reliable, but simpler (Ref. 44). For the determination of Hg contents $\geq 1 \mathrm{ng} / \mathrm{g}$ many other methods come into consideration and may be more economical for routine analysis (Ref. 50).

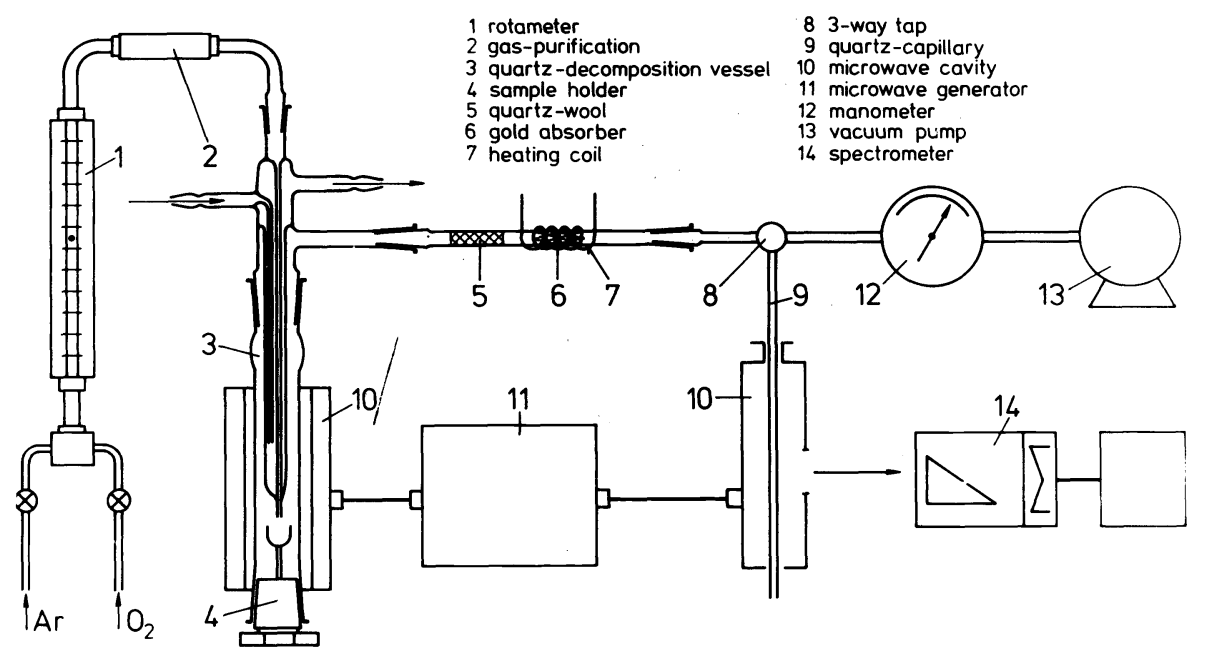

Fig. 6 Decomposition of biotic matrices and rocks in a microwaveinduced oxygen plasma for the enrichment and determination of mercury in the $\mathrm{ng} / \mathrm{g}$ und $\mathrm{pg} / \mathrm{g}-\mathrm{range}$ by MIP-OES

TABLE 3. Limits of Determination of the Sensitive Methods (Selection) for the Determination of Mercury

\begin{tabular}{|c|c|c|c|}
\hline Methods & $\begin{array}{c}\text { Limit of } \\
\text { Determination } \\
{[\mathrm{ng} / \mathrm{mL}]}\end{array}$ & Remarks & References \\
\hline CV-AAS & 0.05 & $\begin{array}{l}\text { after collection } \\
\text { on gold }\end{array}$ & G. Kaiser et al. (44) \\
\hline MIP-OES & 0.0005 & & D. Kollotzek et al. (45) \\
\hline DPASV & 0.001 & & L. Sipos et al. (46) \\
\hline NAA & 0.001 & $\begin{array}{l}\text { after preconcen- } \\
\text { tration on charcoal }\end{array}$ & w. Zonijewska (47) \\
\hline AFA & 0.06 & & $\begin{array}{l}\text { V.I. Muscat, } \\
\text { T.J. Vickers }\end{array}$ \\
\hline $\begin{array}{l}\text { Photo- } \\
\text { metry }\end{array}$ & 1.7 & brilliant green & T. Sawaya et al. (49) \\
\hline
\end{tabular}

\section{Determination of selenium}

The most sensitive Se determination methods are compiled in Table 4 . It has been entirely clarified that HG-AAS is very powerful, but only reliable for pure se solutions. In practical analysis, many concomitant elements have to be taken into account in each complex sample since they may interfere severely with the se-hydride formation, even at the very low concentration levels that are similar to the Se level determined (Ref. 61). By means of some matrix depending tricks such interferences could be eliminated. These interferences used to appear again for unknown reasons when changing the matrix.

Only differential pulse cathodic stripping voltammetry (DPCSV) and gas chromatography with an ECD after separation of Se by way of piazselenol still exceed the detection ability; they are, however, less suitable in routine analysis.

Similarly, we investigated the most important, aforementioned decomposition methods for inorganic and organic materials. Here, we focussed on systematic errors in general and on methods to separate se from elements interfering with HG-AAS as selectively as possible. After comprehensive systematic investiga- 
tions - for some parts in the procedures using the radioactive isotope ${ }^{75}$ Se we then found a combination of methods approximating our ideal conception. It consists of the combustion of the sample in oxygen in the Trace-0-Mat and of subsequent HG-AAS (Ref. 62). In the combustion method which partially involves additives, the $\mathrm{Se}$ regardless its binding is completely volatilized as $\mathrm{SeO}_{2}$ at a corresponding high temperature, thus ensuring a separation from all interfering elements which remain in the combustion residue. The Se, pre-isolated in this way, is transferred into the volatile se-hydride and reliably and economically determined by AAS in the concentration range $\geq 1 \mathrm{ng} / \mathrm{g}$ in most of geochemical and biotic matrices (Ref. 62) and even in fats, greases and oils (Ref. 26). For the determination of $\mathrm{Se}$ in metals and other inorganic solid samples a modified volatilization apparatus must be used (Ref. 63).

TABLE 4. Limits of Determination of Selected Sensitive Methods for the Determination of Selenium

\begin{tabular}{|c|c|c|c|}
\hline Methods & $\begin{array}{l}\text { Limit of } \\
\text { Determi- } \\
\text { nation } \\
{[\mathrm{ng} / \mathrm{mL}]}\end{array}$ & Remarks & References \\
\hline HG-AAS & $\begin{array}{l}0.5 \\
0.005\end{array}$ & $\begin{array}{l}\text { usual } \\
\text { after } \mathrm{SeH}_{2}-\mathrm{coll} \text {. }\end{array}$ & $\begin{array}{l}\text { S. Raptis et al. (51) } \\
\text { J. Piwonka et al. (52) }\end{array}$ \\
\hline HG-MIP-OES & 1 & & $\begin{array}{l}\text { W.B. Robbins, (53) } \\
\text { J.A. Caruso }\end{array}$ \\
\hline HG-AFS & 0.015 & & T. Nakahara et a $1 . \quad(54)$ \\
\hline Furnace-AAS & $0.03 \mathrm{ng}$ & $1 \%$ abs. & R.B. Baird et al. (55) \\
\hline DPCSV & $\begin{array}{l}0.2 \\
0.2\end{array}$ & AC controlled CSV & $\begin{array}{l}\text { G. Henze et al. (56) } \\
\text { K.B. Ebhardt, }(57) \\
\text { F. Umland }\end{array}$ \\
\hline $\begin{array}{l}\text { Piazselenol- } \\
\text { GC }\end{array}$ & $\begin{array}{l}\text { 0.005 ng } \\
\text { abs. }\end{array}$ & & A. Meyer et al. (58) \\
\hline NAA & 0.005 & $\begin{array}{l}\text { preconcentration } \\
\text { on charcoal }\end{array}$ & R. Massée et al. (59) \\
\hline Fluorimetry & 0.03 & $\begin{array}{l}4.5 \text { benzopiaz- } \\
\text { selenol }\end{array}$ & J. Watkinson (60) \\
\hline
\end{tabular}

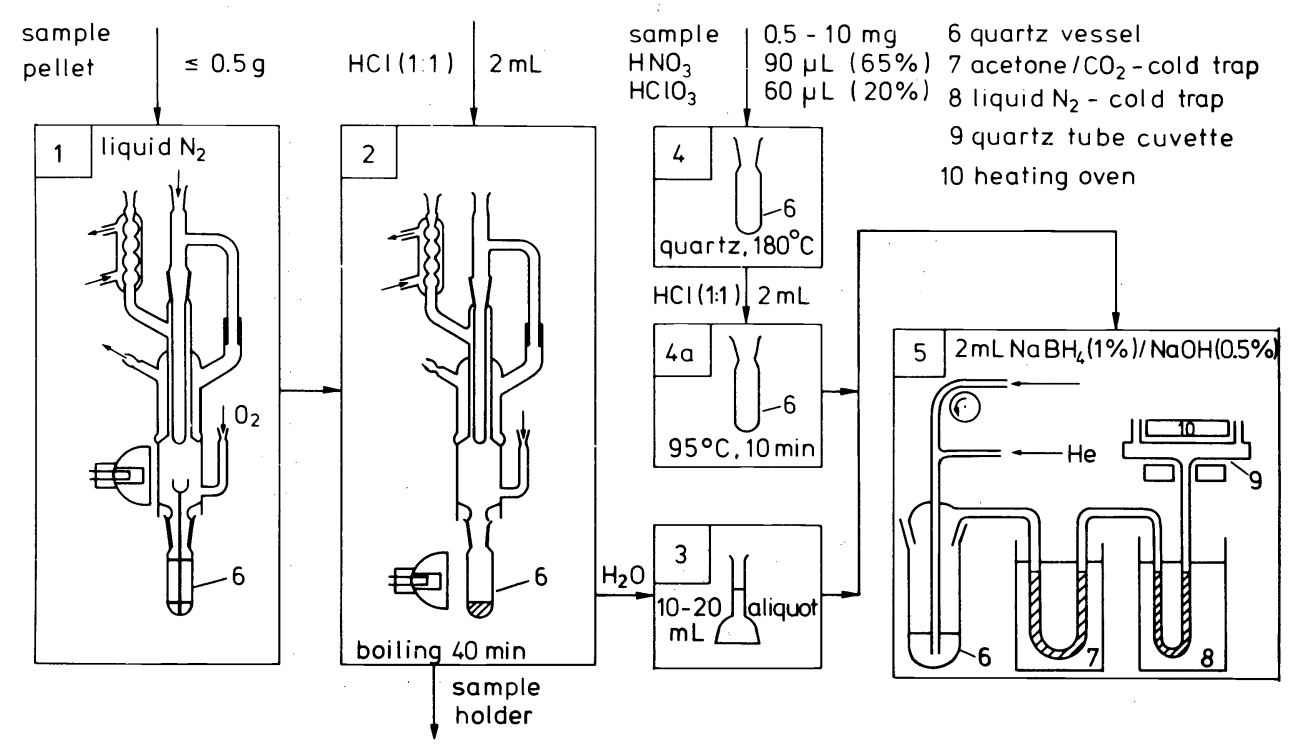

Fig. 7 Flow diagram of the determination of selenium in rocks, soils and biotic materials at the pg/g level after Trace-O-Mat combustion $(1,2)$ by Se-hydride generation-AAs (5) 
A further progress in increasing the sensitivity of the se determination in organic matrices down to $5 \mathrm{pg} / \mathrm{g}$ Se could be obtained by collecting the Sehydride in a special absorber system (Chromosorb in a trap cooled by liquid nitrogen) before AAS-determination (Ref. 52). The flow diagram of the multistage procedure is shown in Fig. 7, and a calibration graph in Fig. 8. This procedure allows to determine the natural se concentration gradient along a single hair or the se concentrations in individual protein fractions of blood serum after their isotachophoretic separation (see Fig. 9) (Ref. 64).

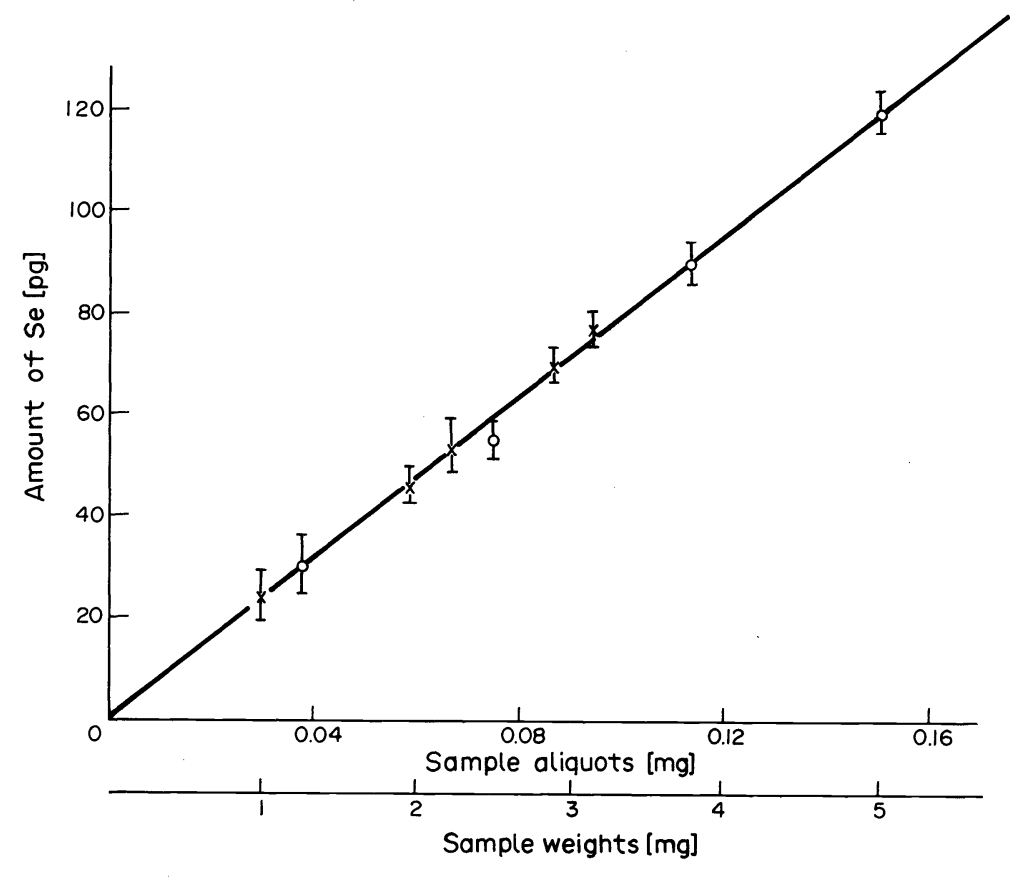

Fig. 8 Calibration graph for the determination

of pg amounts of selenium by HG-AAS

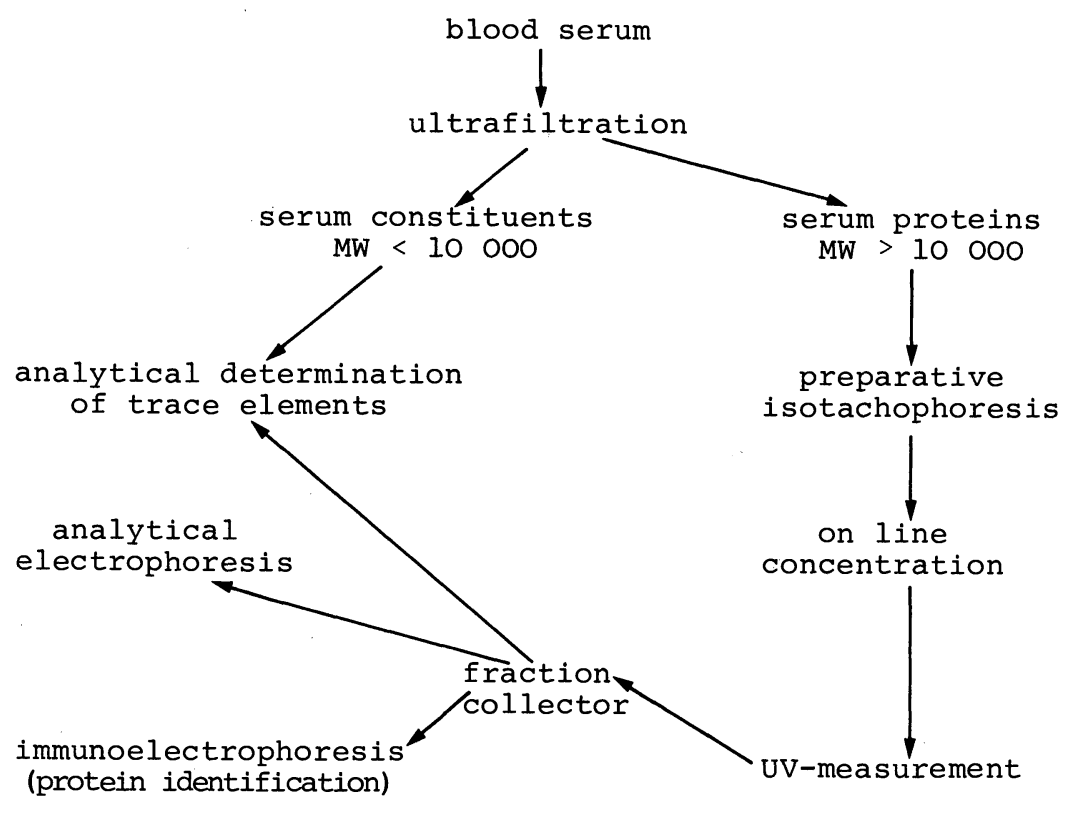

Fig. 9 Block diagram of separation and determination of elements in blood serum and its protein fractions 
3. Determination of thallium

From the most sensitive methods for the Tl determination in pure solutions (Table 5) we found DPASV particularly suitable to develop a very universal, multi-stage procedure for practical purposes (see Fig. 10). After the decomposition of inorganic and organic samples in the Trace-O-Mat, interfering

TABLE 5. Limits of Determination of the Sensitive Methods (Selection) for the Determination of Thallium

\begin{tabular}{|c|c|c|c|}
\hline Methods & $\begin{array}{l}\text { Limit of } \\
\text { Determi- } \\
\text { nation } \\
{[\mathrm{ng} / \mathrm{mL}]}\end{array}$ & Remarks & References \\
\hline $\begin{array}{l}\text { Injection } \\
\text { flame-AAs }\end{array}$ & 12 ng abs. & $40 \mu 1$ & $\begin{array}{l}\text { H. Berndt, } \\
\text { E. Jackwerth }\end{array}$ \\
\hline Loop-AAS & 1 & $40 \mu 1$ & $\begin{array}{l}\text { H. Berndt, } \\
\text { J. Messerschmidt (66) }\end{array}$ \\
\hline Furnace-AAS & 1 & & M. Sager, G. Tölg (67) \\
\hline MIP-OES & 30 & $\begin{array}{l}\text { solution } \\
\text { excitation }\end{array}$ & D. Kollotzek et al. (68) \\
\hline ICP-OES & $\begin{array}{l}0.1 \mathrm{ng} \text { abs. } \\
7\end{array}$ & $\mathrm{HCl} / \mathrm{Ar}$ & $\begin{array}{l}\text { R.K. Skogerboe et al. (69) } \\
\text { M.A. Floyd et al. (70) }\end{array}$ \\
\hline DPASV & $\begin{array}{l}0.5 \\
0.01\end{array}$ & $\begin{array}{l}\text { HMDE } \\
\text { Hg-film-elec- } \\
\text { trode }\end{array}$ & J.E. Bonelli et al. (71) \\
\hline ID-MS & 0.001 & & K.G. Heumann et al. (72) \\
\hline RNAA & 0.5 & $\begin{array}{l}\text { lengthy chem. } \\
\text { separation } \\
203_{\mathrm{Tl}}(\mathrm{n}, 2 \mathrm{n})^{202} \mathrm{Tl}\end{array}$ & J.M. Cohen et al (73) \\
\hline Photometry & 10 & $\begin{array}{l}{\left[\mathrm{TlBr}_{4}\right] \text {-rhoda- }} \\
\text { mine B }\end{array}$ & M. Sager, G. Tölg (74) \\
\hline
\end{tabular}

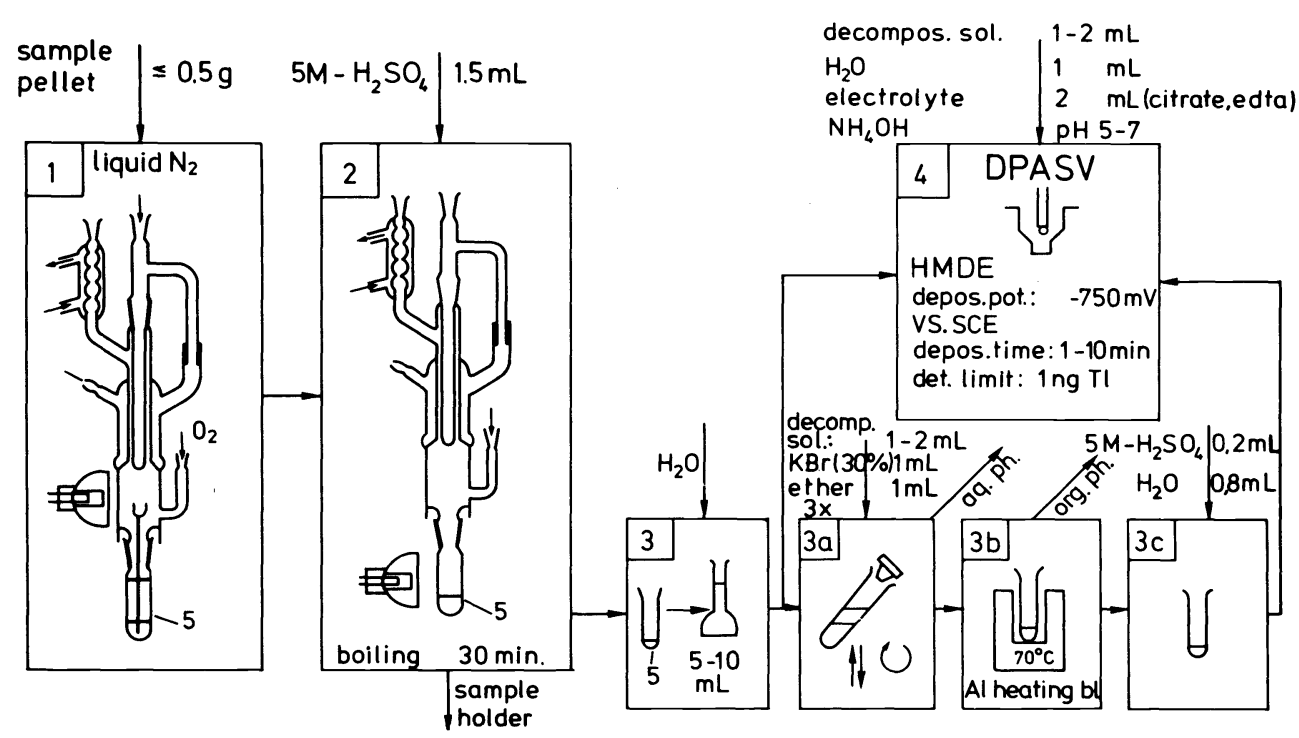

Fig. 10 Flow diagram of the determination of thallium in rocks, soils and biotic materials after Trace-O-Mat combustion $(1,2)$, by DPASV (4) or Trace-O-Mat combustion, Tl(III)-bromide extraction ( $3 \mathrm{a}, 3 \mathrm{~b}, 3 \mathrm{c}$ ) and DPASV, quartz tube (5) 
elements can be separated by volatilization of the Tl traces during the decomposition step to such an extent that only in some special cases a second separation step by extraction of the Tl(III)-bromide complex with diisopropyl ether is required prior to the determination of Tl by DPASV. All operations for the Tl isolation will be carried out in the same quartz tube (see Fig.10, 5) which contains the Tl after the decomposition step. Inorganic samples ( $\leq 0.5 \mathrm{~g}$ ) will be pulverized (e.g., rocks, soils, cement), mixed with cellulose powder and pressed to pellets which will be burnt in the Trace-O-Mat.

Following this principle, Tl contents of $\geq 2 \mathrm{ng} / \mathrm{g}$ can be determined in nearly all inorganic and organic matrices with high accuracy (Table 6) (Ref. 75). The sample weight-to-cellulose ratio depends on the kind of the sample matrix.

TABLE 6. Determination of Thallium in Rocks and Biotic Materials by ASV

\begin{tabular}{|c|c|c|c|}
\hline Matrix & $\begin{array}{l}\text { T1 } \\
\text { Trace-o-Mat } \\
\text { direct }\end{array}$ & $\begin{array}{l}\text { Concentration } \\
\text { decomposition } \\
\text { T1 extracted }\end{array}$ & $\begin{array}{l}\text { g/g] } \\
\text { Wet decomposition } \\
\text { T1 extracted }\end{array}$ \\
\hline $\begin{array}{l}\text { Granite } \\
\text { USGS-G } 2\end{array}$ & 700 & 710 & 680 \\
\hline $\begin{array}{l}\text { Andesite } \\
\text { USGS-AGV } 1\end{array}$ & 270 & 260 & 280 \\
\hline $\begin{array}{l}\text { Granodiorite } \\
\text { USGS-GSP } 1\end{array}$ & 930 & 910 & \\
\hline $\begin{array}{l}\text { Al.btalgranite } \\
\text { DFG-KA-1 }\end{array}$ & 1050 & & 1100 \\
\hline $\begin{array}{l}\text { Dazite } \\
\text { DFG-KA-2 }\end{array}$ & 130 & 120 & 130 \\
\hline $\begin{array}{l}\text { Tomato leaves } \\
\text { NBS }-1573\end{array}$ & 24 & 20 & \\
\hline $\begin{array}{l}\text { Pine needles } \\
\text { NBS }-1575\end{array}$ & 27 & 30 & \\
\hline $\begin{array}{l}\text { Orchard leaves } \\
\text { NBS-1571 }\end{array}$ & 31 & 27 & 35 \\
\hline $\begin{array}{l}\text { Rice flour } \\
\text { NBS } 1568\end{array}$ & $<2$ & $<2$ & \\
\hline $\begin{array}{l}\text { Wheat flour } \\
\text { NBS-1567 }\end{array}$ & 2 & 3 & \\
\hline
\end{tabular}

4. Determination of boron

Some very sensitive methods to determine boron in pure solutions are given in Table 7. Boron determination in complex matrices, however, (e.g., in high-purity metals, silicon, quartz) leads already at the lower $\mu \mathrm{g} / \mathrm{g}$ level to serious problems with respect to sensitivity and accuracy. Therefore, boron must be separated from many interfering elements prior to its determination. Since some years, we have worked out reliable multi-stage procedures for different sample groups with good progress (see Fig. 11).

If the sample has to be dissolved in a mixture of hydrofluoric acid with other agents (sample group $\mathrm{A}$ : e.g., $\mathrm{Zr}, \mathrm{Nb}, \mathrm{Si}$, quartz) boron can be separated as $\mathrm{BF}_{3}$ in ng quantities during the decomposition step. The $\mathrm{BF}_{3}$ evolved is transferred by a carrier gas from the PTFE-decomposition vessel into the receiver of the decomposition apparatus (see Fig. 12). Before its determination by ICP-OES, it is necessary to separate and concentrate the boron from the hydrofluoric acid distillate. This is done by extracting it as $\mathrm{BF}_{4}$-tetrabutylammonium complex $\left(\mathrm{BF}_{4}-\mathrm{TBA}\right)$ with $\mathrm{MIBK}$. Then the organic phase can be directly sprayed into the ICP or CMP for the emission spectroscopic determination (Ref. 81). For the sample group B (e.g., Mo, W, Al, steel) (see Fig. 11) an acid decomposition under oxydizing conditions produces boric acid which can be separated by distillation of the boric acid methyl ester and/or the extraction with 2-ethyl-1,3-hexandiol (EHD) (Ref. 82). For the $\mathrm{B}\left(\mathrm{OCH}_{3}\right) 3_{\text {-distillation, }}$ a special circulation distillation device (quartz) has been developed (see Fig. 13); it shows in comparison to a normal distillation technique essential advantages in the yield of very low amounts of boron. 
TABLE 7. Limits of Determination of the Sensitive Methods (Selection) for the Determination of Boron (Pure Solutions)

\begin{tabular}{|c|c|c|c|}
\hline Methods & $\begin{array}{l}\text { Limit of } \\
\text { Determination } \\
{[\mathrm{ng} / \mathrm{mL}]}\end{array}$ & Remarks & References \\
\hline MIP-OES & 100 & $\begin{array}{l}\text { excitation of solu- } \\
\text { tions (HC-Ar-MIP) }\end{array}$ & D.Kollotzek (68) \\
\hline CMP-OES & 40 & & A. Disam et al. (76) \\
\hline ICP-OES & 3.2 & $\lambda=249.7 \mathrm{~nm}$ & P.W.J.M. Boumans (77) \\
\hline HC-OES & 1 & $\begin{array}{l}\text { solution residue } \\
\text { on silver }\end{array}$ & P. Faßmann (78) \\
\hline \multirow[t]{2}{*}{ Photometry } & 2 & $\begin{array}{l}\text { after extraction as } \\
{\left[\mathrm{BF}_{4}\right] \text {-methylene blue }}\end{array}$ & L. Pasztor et al (79) \\
\hline & 0.8 & $\mathrm{~B}(\mathrm{OH})_{3}$-curcumin & $\begin{array}{l}\text { D. Thierig, (80) } \\
\text { F. Umland }\end{array}$ \\
\hline
\end{tabular}

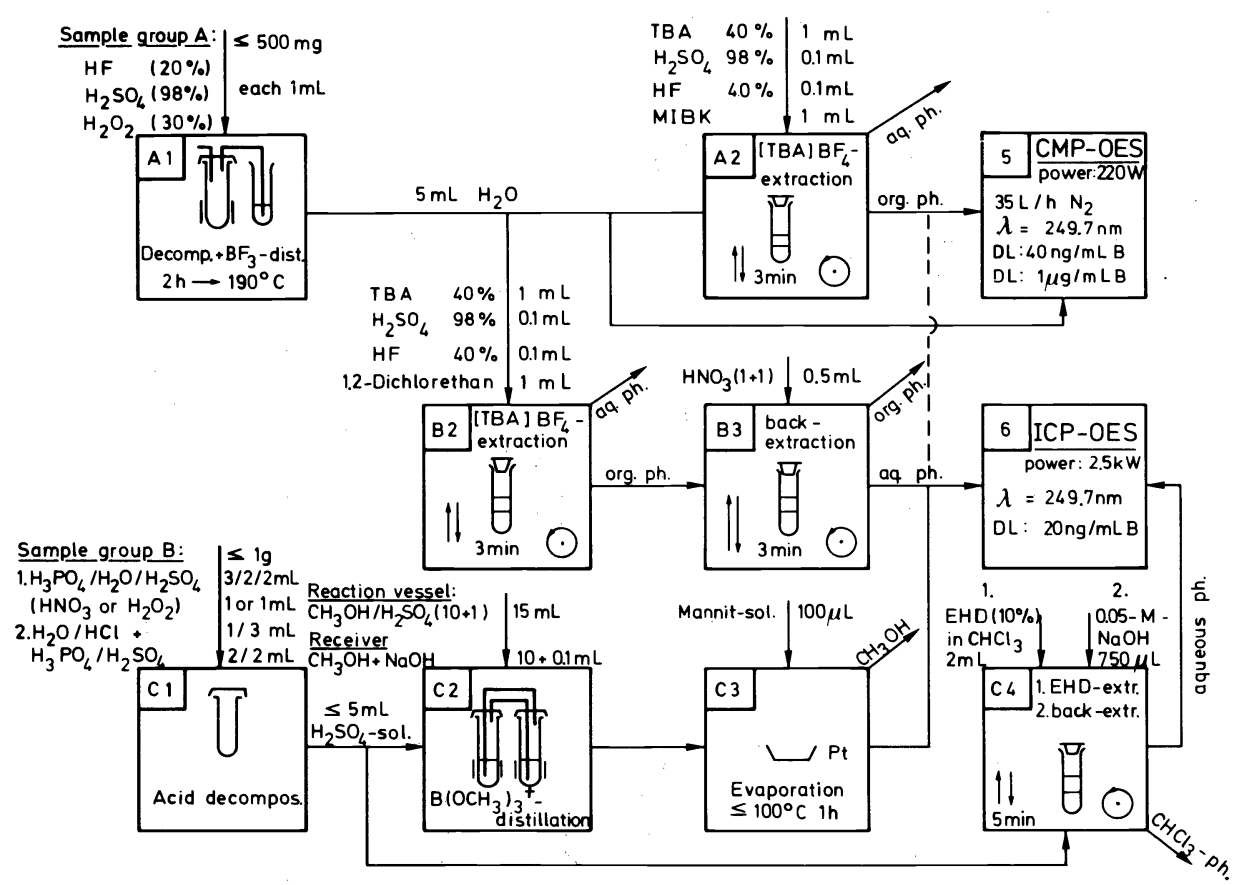

Fig. 11 Flow diagram of the determination (CMP-OES and ICP-OES) of $B$ in metals, silicon and quartz at the $\mathrm{ng} / \mathrm{g}$ level after sample decomposition and preconcentration $\left(\mathrm{BF}_{3}-\right.$ or $\mathrm{B}\left(\mathrm{OCH}_{3}\right)_{3}$-distillation); sample group $\mathrm{A}$ : $\mathrm{Si}, \mathrm{SiO}_{2}, \mathrm{Al}, \mathrm{Zr}$, Nb etc; sample group $\mathrm{B} 1$ : Mo, W; sample group B2: steel, Al; TBA: Tetrabutylammonium hydroxyde; EHD: 2-Ethyl-1,3-hexandiol

The accuracy of the different procedures was proven with many different materials; a selection is presented in Table 8 . All results obtained with the different procedures are in good agreement, also with data of other laboratories.

\section{CONCLUSION}

This contribution is to demonstrate that the role of multi-stage procedures in elemental trace analysis cannot be generalized. The importance of these procedures in the $\mu \mathrm{g} / \mathrm{g}$ trace analysis has diminished in favour of instrumental methods. In the $\mathrm{ng} / \mathrm{g}$ and even more so in the $\mathrm{pg} / \mathrm{g}$ analysis, multi-stage procedures are as long indispensible, and consequently more economical, as instrumental direct methods are not yet of sufficiently high sensitivity and/or reliability to solve the problems in extreme trace analysis. 


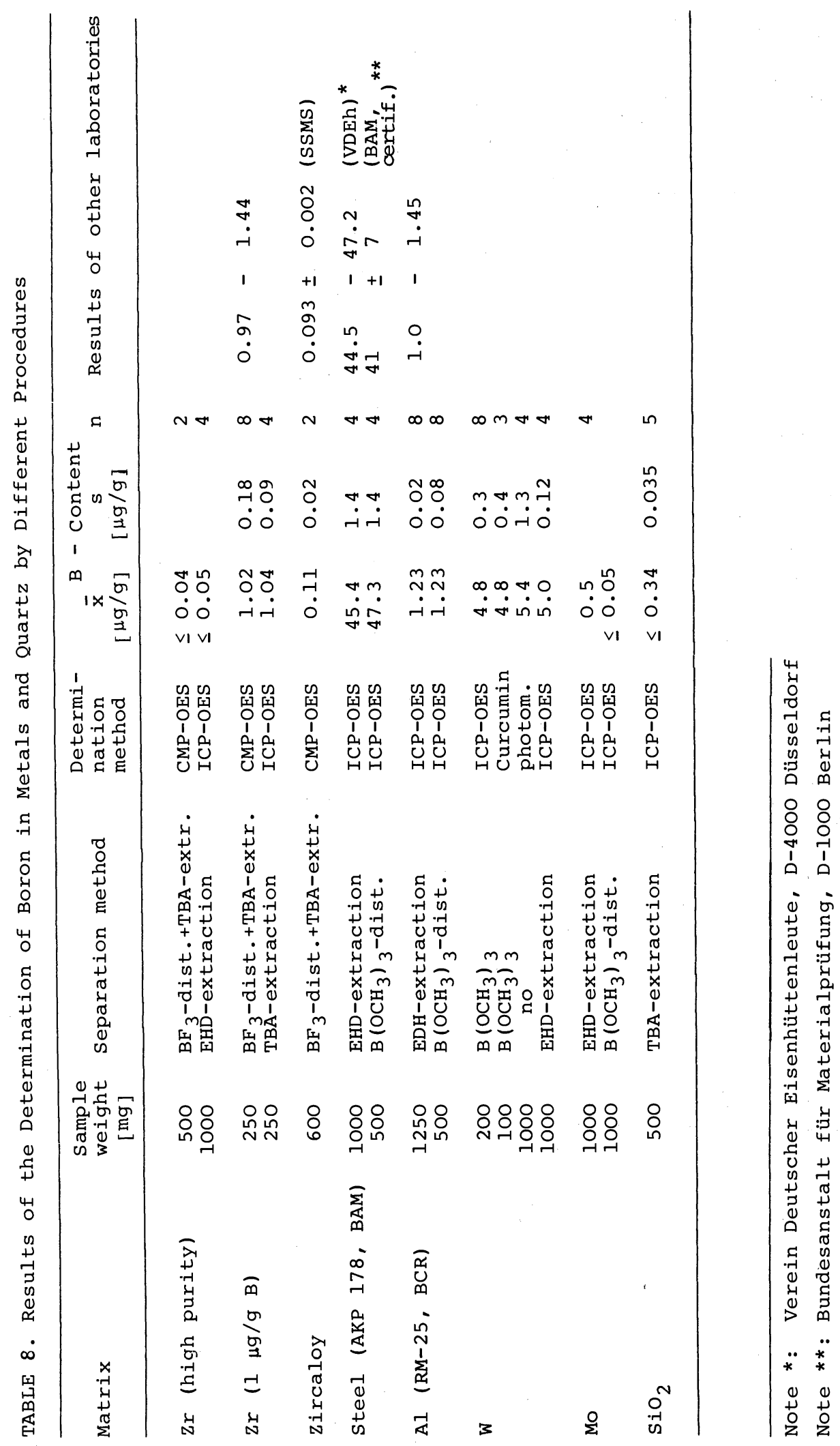




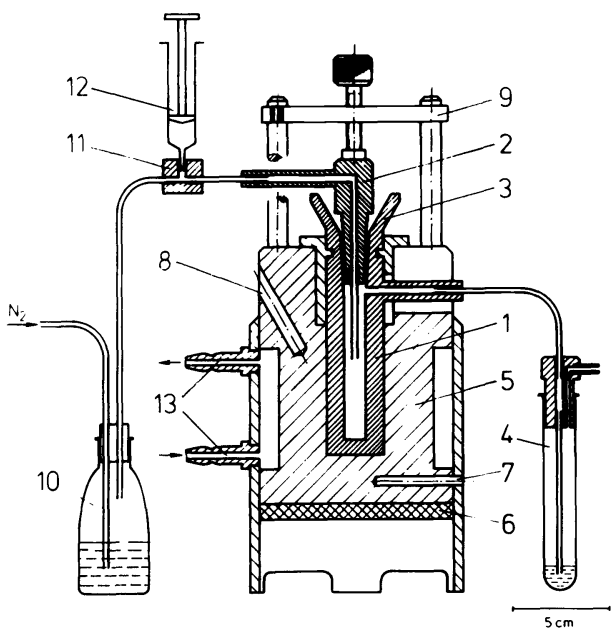

1 distillation vessel (PTFE)

2 PTFE-stopper with gas inlet tube

3 PTFE-sleeve

4 receiver (PP-tube)

5 heating furnace

(stainless steel)

6 heating plate $(600 \mathrm{~W})$

7 hole for NTC resistor

8 hole for thermometer

9 support for 2

10 washing flask

$11 \mathrm{~T}$-connection

12 syringe (PE)

13 water cooling

Fig. 12 Apparatus for sample decomposition and separation of boron by distillation as $\mathrm{BF}_{3}$
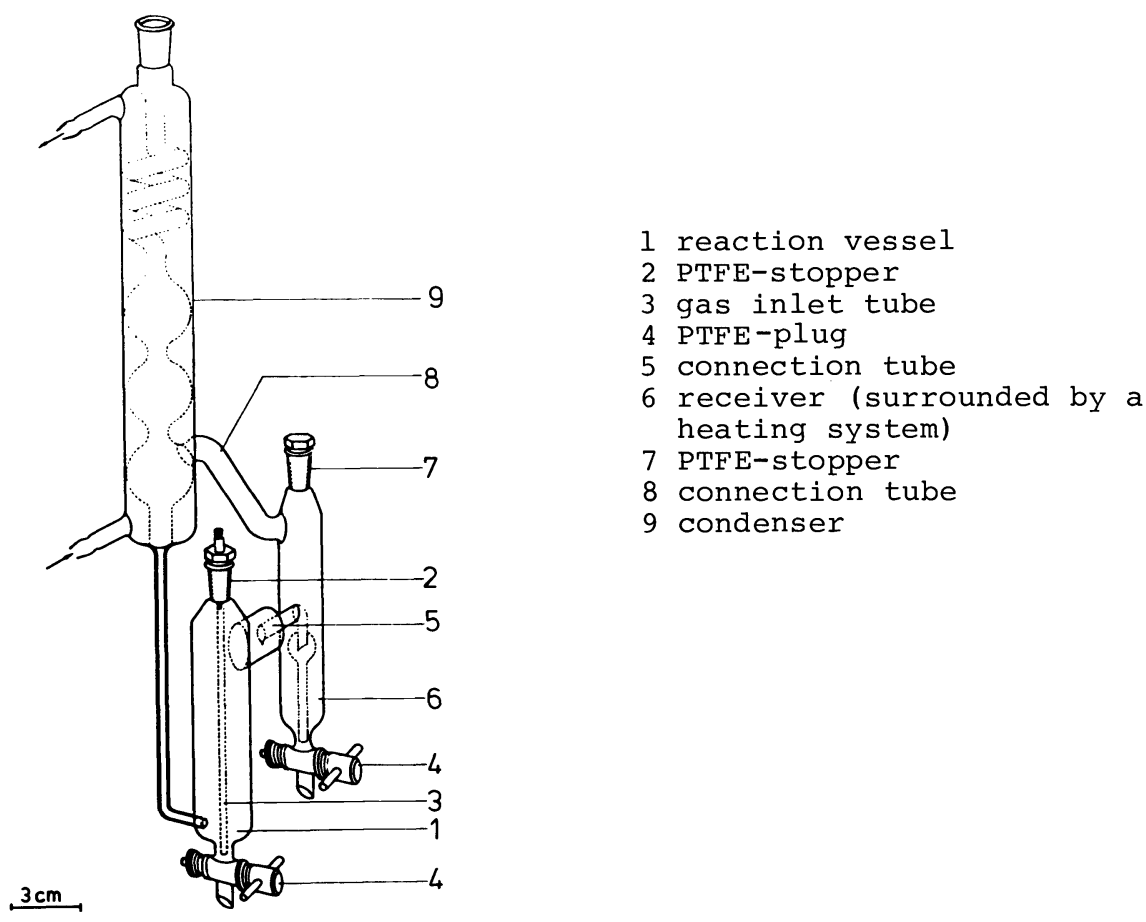

Fig. 13 Circulation distillation apparatus (quartz) for the separation of boron traces as boric acid methyl ester

The main point in developing multi-stage procedures is not the labour intensive or time consuming procedure nor is it the economic factor. It is the requirement that the analytical chemist should develop an attitude of profound criticism and that he should apply all experiences. Till now no better approach has been developed. 


\section{REFERENCES}

1. G. Tölg, Naturwiss. 63, 99-110 (1976).

2. G. Tölg, Recent Developments in Food Analysis (Eds. W. Baltes et al.), .Verlag Chemie, Weinheim, pp. 335-355 (1982).

3. Collaborative Interlaboratory Studies in Chemical Analysis (Eds. E. Harold and T.S. West), IUPAC, Pergamon Press, Oxford (1982).

4. G. Tölg, Fresenius Z. Anal.Chem. 294, 1-15 (1979).

5. P. Tschöpel and G. Tölg, J. Trace and Microprobe Techniques 1, 1-77 (1982).

6. V. Krivan, Talanta 29, 1041-1050 (1982).

7. L. Kotz, W. Schulz, P. Tschöpel, P. Veber and G. Tölg, Fresenius Z. Anal. Chem. 302, 1-14 (1980).

8. K. Gretzinger, L. Kotz, P. Tschöpel and G. Tölg, Talanta 29, 1011-1018 (1982).

9. L. Mart, Fresenius Z. Anal. Chem. 296, 350-357 (1979).

10. L. Kosta, Talanta 29, 985-992 (1982).

11. J.W. Mitchell, Talanta 29, 993-1002 (1982).

12. J.W. Mitchell, J. Radioanal. Chem. 69, 47-105 (1982) .

13. K. Heydorn and E. Damsgaard, Talanta 29, 1019-1024 (1982).

14. M. Stöppler, H.W. Dürbeck and H.W. Nürnberg, Talanta 29, 963-972 (1982).

15. P. Tschöpel in:Ullmanns Encyclopädie der technischen Chemie, Bd. 5, Verlag Chemie, Weinheim, pp. 27-40 (1980).

16. G. Knapp in:Atomspektrometrische Spurenanalytik (Ed. B. Welz), Verlag Chemie, Weinheim, pp. 151-159 (1982).

17. K. May and M. Stoeppler, Fresenius Z. Anal. Chem. 293, 127-130 (1978).

18. S. Bajo, U. Suter and B. Aeschliman, Anal. Chim. Acta 149, 321-335 (1983).

19. L. Kotz, G. Henze, G. Kaiser, S. Pahleke, M. Veber and G. Tölg, Talanta 26, 681-691 (1979).

20. R. Uhrberg, Anal. Chem. 54, 1906-1908 (1982).

21. S. Raptis, G. Knapp and A.P. Schalk, Fresenius Z. Anal. Chem., in press.

22. E.V. Williams, Analyst 107, 1006-1013 (1982).

23. G. Kaiser, P. Tschöpel and G. Tölg, Fresenius Z. Anal. Chem. 253, 177-179 (1971).

24. E. Scheubeck, J. Gehring and M. Pickel, Fresenius Z. Anal. Chem. 297, 113-116 (1979).

25. G. Knapp, S. Raptis, G. Kaiser, G. Tölg, P. Schramel and B. Schreiber, Fresenius Z. Anal. Chem. 308, 97-103 (1981).

26. S. Raptis, G. Kaiser and G. Tölg, Anal. Chim. Acta 138, 93-101 (1982).

27. H.B. Han, G. Kaiser and G. Tölg, Anal. Chim. Acta $1 \frac{134}{3}, 3-11$ (1982) .

28. F.A. Armstrong, P.M. Williams and J.D. Strickland, Nature 211, 481-483 (1966).

29. L. Sipos, J. Golimowski, P. Valenta and H.W. Nürnberg, Fresenius Z. Anal. Chem. 298, 1-8 (1979).

30. P. Burba and P.G. Willmer, Fresenius Z. Anal. Chem. 311, 222-231 (1982).

31. Yu.A. Zolotov, Pure and Appl. Chem. 50, 129-148 (1978).

32. E. Jackwexth, A.Mizuike, Yu.A. Zolotov, H. Berndt, R. Höhn and N.M.Kuz'min, Pure and Appl. Chem. 51, 1195-1211 (1979).

33. K. Bächmann, Multielement Concentration for Trace Elements; CRC Critical Reviews in Analytical Chemistry, Vol. 12/I, 1-67 (1981).

34. N.M. Kuz'min, Zavod. Lab. 48, No. $2,11-15$ (1982).

35. J. Minczewski, J. Chwastowska and R. Dybczynski, Separation and Preconcentration Methods in Inorganic Trace Analysis, Ellis Horwood Ltd., Chichester (1982).

36. A. Mizuike, Enrichment Techniques for Inorganic Trace Analysis, SpringerVerlag, Berlin/Heidelberg/New York (1983).

37. R. van Grieken, Anal. Chim. Acta 143, 3-34 (1982).

38. R.T. Ellis, D.E. Leyden, W. Wegscheider, B.B. Jablonski and W.B. Bodnar, Anal. Chim. Acta 142, 73-87 (1982).

39. Th. Stiefel, K.Schulze, H. Horn and G. Tölg, Anal. Chim. Acta 87, 67-78 (1978).

40. Th. Stiefel, K. Schulze, G. Tölg and H. Zorn, Fresenius Z. Anal. Chem. 300, 189-196 (1980) .

41. G. Schwedt in: Analytiker-Taschenbuch, Bd. 3 (Eds. R. Bock et al.), Springer-Verlag Berlin/Heidelberg/New York, pp. 161-179 (1981).

42. J. Horrion, J. Vandegans, J.P. Hartmann and J.P. Leemans; Congr. FATIPEC 16 th, pp. 175-187 (1982).

43. G. Tölg in: Nature, Aim and Methods of Microchemistry (Eds. H. Malissa et al.), Springer-Verlag Wien/New York, pp. 203-230 (1981).

44. G. Kaiser, D. Götz, G. Tölg, G. Knapp, B. Maichin and H. Spitzy, Z. Anal. Chem. 291, 278-291 (1978).

45. D. Kollotzek, P.Tschöpel and G. Tölg, unpublished. 
46. E. Sipos, P. Valenta, H.W.Nürnberg and M. Branca, J. Electroanal. Chem. 77, 263-266 (1977).

47. W. Zonijewska, J. Radioanal. Chem. 35, 389-418 (1977) .

48. V.I. Muscat and T.J. Vickers, Anal. Chim. Acta 57, 23-30 (1971).

49. T. Sawaga, H. Ishii and T. Odashima, Bunseki Kagaku 22, 318-322 (1973).

50. G. Kaiser and G. Tölg in: The Handbook of Environmental Chemistry, Vol. 3 , Part A (Ed. O. Hutzinger), Springer-Verlag Berlin/Heidelberg/New York, pp. 1-58 (1980).

51. S. Raptis, G. Kaiser and G. Tölg, Fresenius Z. Anal. Chem., in press.

52. J. Piwonka, G. Kaiser and G. Tölg, unpublished.

53. W.B. Robbins and J.A. Caruso, Anal. Chem. 51, 889A-899A (1979).

54. T. Nakahara et al., Appl. Spectrosc. $34,194-200$ (1980).

55. R.B. Baird, S. Pourian and S.M. Gabrielian, Anal. Chem. 44, 1887-1889(1972).

56. G.Henze, P. Monks, G. Tölg, F. Umland and E. WeBling, Fresenius Z. Anal. Chem. 295, 1-6 (1979) .

57. K.B. Ebhardt and F. Umland, Fresenius Z. Anal. Chem. 310, 406-409 (1982).

58. A. Meyer, E. Grallath, G. Kaiser and G. Tölg, Fresenius Z. Anal. Chem. 281, 201-209 (1976).

59. R. Massée, H.A. van de Sloot and H.A. Das, J. Radioanal. Chem. 35, 157-165 (1977)

60. J.H. Watkinson, Anal. Chim. Acta 134, 417-419 (1982).

61. A. Meyer, Ch. Hofer, G. Tölg, S. Raptis and G. Knapp, Fresenius Z. Anal. Chem. 296, 337-344 (1979).

62. Heng-Bin Han, G. Kaiser and G. Tölg, Anal. Chim. Acta 128, 9-21 (1981).

63. A. Meyer, Ch. Hofer, G.Knapp and G. Tölg, Fresenius Z. Anal. 305, 1-10(1981).

64. Th. Stiefel, K. Schulze and G. Tölg in: Trace Element Analytical Chemistry in Medicine and Biology (Eds. P. Brätter, P. Schramel), Walter de Gruyter Berlin/New York, pp.439-453 (1980).

65. H. Berndt and E. Jackwerth, Spectrochim. Acta 30B, 169-177 (1975).

66. H. Berndt and J. Messerschmidt, Spectrochim. Acta 36B, 809-819 (1981).

67. M. Sager and G. Tölg in: Analytiker-Taschenbuch, Bd. 4 (Eds R. Bock et al.) Springer-Verlag Berlin/Heidelberg/New york, in press.

68. D. Kollotzek, P. Tschöpel and G. Tölg, Spectrochim. Acta, Part B, in press.

69. R.K. Skogerboe, D.L. Diek, D. Zavlica and F.E. Lichte, Anal. Chem. 47, 568-570 (1975)

70. M.A. Floyd, V.A. Fassel, R.K. Winge, J.M. Katzenberger and A.P.D. Silva, Anal. Chem. 52, 431-438 (1980).

71. J.E. Bonelli, H.E. Tayla and R.K. Skogerboe, Anal. Chim. Acta 118, 243-256 (1980).

72. K.G. Heumann, P. Kastenmayer and H. Heininger, Fresenius Z. Anal. Chem. 306, 173-177 (1981);

K.G. Heumann and J. Trettenbach, personal information

73. I.M. Cohen, S.M. Respizky and B.G. Baro, J. Radianal. Chem. 72, 451-461 (1982).

74. M. Sager and G. Tölg, Mikrochim. Acta 231-245 (1982/II).

75. I. Liem, G. Kaiser, M. Sager and G. Tölg, Fresenius Z. Anal. Chem., in press.

76. A. Disam, P. Tschöpel and G. Tölg, Fresenius Z. Anal. Chem. 310, 131-143 $(1982)$.

77. P.W.J.M. Boumans, Spectrochim. Acta 36B, 169-203 (1981).

78. P. Faßmann, Dissertation Universität Stuttgart (1980).

79. L. Pasztor, J.D. Bode and A. Fernando, Anal. Chem. 32, 277-281 (1960).

80. D. Thierig and F. Umland, Fresenius Z. Anal. Chem. $211,161-169$ (1965).

81. E. Grallath, P. Tschöpel, G. Kölblin, U. Stix and G. Tölg, Fresenius Z. Anal. Chem. 302, 40-51 (1980) .

82. G. Mezger, E. Grallath, U. Stix and G. Tölg, Fresenius Z. Anal.Chem., in press. 